\title{
The Pill Really Can Be Mightier Than the Sword: A Response to Recent Commentaries
}

\author{
Malcolm Potts*, Alisha Graves \\ Abstract \\ We appreciate the four commentaries that add new material and fresh perspectives to our article "The pill is mightie \\ than the sword." In emphasizing the role of voluntary family planning and girls' education as achievable strategies \\ with a potential to make the world a more peaceable place, we did not mean to oversimplify or disregard the intrinsic \\ complexity of human conflict. On the whole, the commentators support and add to our thesis, although we question \\ Pillai and Ya-Chien Wang's suggestion that we may have overstated the unique human predisposition to kill our own \\ species. We present additional data on male team aggression. \\ Keywords: Family Planning, Girls' Education, Terrorism, Population \\ Copyright: (c) 2016 by Kerman University of Medical Sciences \\ Citation: Potts M, Graves A. The pill really can be mightier than the sword: a response to recent commentaries. Int J \\ Health Policy Manag. 2016;5(3):219-220. doi:10.15171/ijhpm.2016.02
}

Article History:

Received: 20 December 2015 Accepted: 30 December 2015
ePublished: 6 January 2016
$\mathrm{W}$ e value the four commentaries on our paper (The pill is mightier than the sword), and we appreciate the richness of the comments and depth of knowledge of the commentators. Ilsa Lottes ${ }^{1}$ added data we had not seen ourselves about the correlation between high birth rates, a youth bulge and conflict and terrorism. At the same time, along with most of the other commentators, Lottes rejects "ideas that emphasize only one factor as a major cause of any social phenomenon." We also accept that generalization, and apologize if we failed to give it sufficient prominence when telling our own particular story.

Roger-Mark De Souza ${ }^{2}$ adds two valuable perspectives to our basic argument. He documents how the defense community is beginning to recognize the role the autonomy of women can play in facilitating peace. Secondly, De Souza reminds us of the tribal congressional politics in Washington that continually undermine programs aimed at giving women the family planning choices they need and deserve. We see this political trend as growing out of the same patriarchal male drives that leads to team aggression, warfare and terrorism. ${ }^{3}$ Ultimately, patriarchy is an expression of the male reproductive agenda: a woman's ability to control her own fertility is perceived as threatening to a man's competitive drive. Perhaps the greatest patriarch of all time was the Mongol Emperor Genghis Khan (died 1227). He raped the women he captured and modern gene analysis suggests that most plausible explanation of the fact that 16 million men in the contemporary world have identical Y chromosomes is that they are linear descendants of Genghis Khan. Genghis Khan is an unfortunate role model for any contemporary politician, but his story underscores the need to reframe discussions of war, terrorism and the autonomy of women.

We are grateful to Raymond Gilpin ${ }^{4}$ for adding the perspective of a Defense University security expert to the debate. We certainly accept his insistence that, "Efforts to modify the population structure would only be effective if they are conducted in concert with initiatives that improve governance, promote broad-based economic welfare, and guarantee basic human rights for all." We also see how "Representative governance is a central element of this strategy." The problem, however, is that Afghanistan, Iraq, Syria, Yemen and parts of the Sahel (which are the focus of our research) are many decades - perhaps even longer - from a fully functioning representative government. Meanwhile, making family planning available but can, and should, begin immediately.

We also appreciate Vijayan Pillai and Ya-Chien Wang's support for way educating women contributes to peace. ${ }^{5}$ We accept the role of culture in modulating both male and female aggression, but we feel they overstate the case. We are a uniquely violent species. Only a handful of mammals systematically and deliberately kill other members of our own species. Fortunately, measured as a ratio of deaths from violence in the total population, the twentieth century was probably one of the least violent times on history. ${ }^{6}$ Among preliterate groups living a Stone Age way of life in New Guinea, $20 \%$ to $30 \%$ of men were killed by other men. ${ }^{7,8}$ Among the Yanamamo in South America, four out of 10 adults have participated in killing another human being and $60 \%$ of this $40 \%$ have been involved in more than one person. The 9/11 attacks killed one in 100000 Americans.

Among hyenas, which also seem to engage in same species killing, it is the females who are the aggressors. Women will fight bravely to defend themselves or their children, but in the whole sweep of human history there is not one example of women banding together to spontaneously attack and kill other human beings - something that men have done countless times during the whole course of human history. We should be grateful that we live in a relatively peaceful world. The Islamic State and Boko Haram are the default position for human behavior. While such violence was once widespread it is now localized. 
It is important to avoid the mistake made by UNESCO in the 1986 Saville Statement ${ }^{9}$ when many psychologists, anthropologists and sociologist bought into a statement that, "It is scientifically incorrect to say that war or any other violent behavior is genetically programed into human nature." Shortly after that statement Jane Goodall discovered that our closest relative - chimpanzees - also engage in same species killing, and up to one third of adult chimps are killed by other chimps. ${ }^{10}$ While emphasizing our brutal heritage, we also want to emphasize that we are not condemned to follow our violent predispositions. We are grateful to the commentators and hope that together we can contribute to an important debate on helping women to wage peace.

\section{Ethical issues}

Not applicable.

\section{Competing interests}

Authors declare that they have no competing interests.

\section{Authors' contributions}

MP and AG contributed equally to the writing of this article.

\section{References}

1. Lottes IL. The pill vs. the sword: additional considerations: Comment on "The pill is mightier than the sword." Int $J$ Health Policy Manag. 2015;4(12):853-855. doi:10.15171/ ijhpm.2015.155

2. De Souza RM. A little bit of sugar helps the pill go down: resilience, peace, and family planning: Comment on "The pill is mightier than the sword." Int $J$ Health Policy Manag. 2016; forthcoming. doi:10.15171/ijhpm.2015.175

3. Potts $M$, Campbell M. The origins and future of patriarchy: the biological background of gender politics. Journal of Family Planning and Reproduction Health Care. 2008;34(2):171-174.

4. Gilpin R. Bomb or boon: linking population, people and power in fragile regions: Comment on "The pill is mightier than the sword." Int J Health Policy Manag. 2016;5(2):113-1116. doi:10.15171/ ijhpm.2015.176

5. Pillai VK, Wang YC. Women's education and world peace: a feminist dream comes true: Comment on "The pill is mightier than the sword." Int J Health Policy Manag. 2016;5(2):107-108. doi:10.15171/ijhpm.2015.178

6. Potts M, Hayden T. Sex and War: How Biology Explains Warfare and Terrorism and Offers a Path to a Safer World. Dallas: Benbella Books; 2008.

7. Mesquida CG, Wiener NI. Yanamamo. Fort Worth: Harcourt Brace; 1997.

8. Mesquida CG, Wiener NI. Life histories, blood revenge, and warfare in a tribal people. Science. 1988;239:985-992.

9. Adam D. War is Not in Our Biology: A Decade of the Seville Statement. In Violence: From Biology to Society. New York: Elsevier; 1997.

10. Wrangham R, Peterson D. Demonic Males: Apes and the Origin of Human Violence. Boston; Houghton Mifflin; 1996. 